\title{
Belfries, Cloth Halls, Hospitals, and Mendicant Churches: A New Urban Architecture in the Low Countries around 1300
}

\author{
Thomas CoOMANS ${ }^{1}$
}

The view we have of the architecture in the years around 1300 is retrospective, and therefore our perception of that time is altered by our awareness of what happened later. What was modern then is today considered only a moment on the timeline in a centurieslong evolution. Most importantly, the knowledge we have of the generation of buildings created seven hundred years ago is very fragmentary and depends heavily on survival, on their present state of preservation, and on their dating - which is seldom accurate.

The enormous building activity that took place in the cities of the Low Countries in the fifteenth and sixteenth centuries resulted in a considerable loss of earlier architecture, especially of houses. Nearly all medieval wooden houses have disappeared thanks to the introduction of new fire prevention regulations in building construction in the fourteenth century and new sanitation norms in the nineteenth century. ${ }^{2} \mathrm{Nei}-$ ther archaeology, which is generally limited to the subject of early medieval urban wooden housing, ${ }^{3}$ nor iconographical sources provide us with much information, but one must assume that wooden architecture was predominant in towns around 1300 .

In this contribution I would like to focus on the new urban architecture that was developed by a new class of patrons at the end of the thirteenth century. Never before had cities been so wealthy and as populated. A fundamental economic change occurred around 1300 when many towns ceased to hold annual fairs and began to export the products of the surrounding regions directly to a much larger network of con- sumers. ${ }^{4}$ The new merchant elite had a strong sense of their own economic and political power, thanks to the freedoms that cities had gradually acquired from the princes. In this changing society, a new balance had to be found not only between the merchants and the nobility, but also between the church, the new urban religious orders, the lower social classes of craftsmen, the poor, and the sick.

\section{A forgotten generation in the history of architecture}

Historians of Gothic architecture in the Low Countries traditionally consider the turn of the fourteenth century as a period of transition between two great periods of economic growth. ${ }^{5}$ The first period spanned the first generations of Early and High Gothic architecture, which was directly influenced by the nearby centres of the Île de France, Oise, and Picardie, and culminated in the building of the cathedrals of Liège, Cambrai, and Tournai in the first three quarters of the thirteenth century. ${ }^{6}$ From the second half of the thirteenth century, Gothic influence also emanated from the workshop of the cathedral of Cologne.

The second period, from the mid-fourteenth century onwards, saw the flourishing of late Gothic architecture in the great merchant cities of the Low Countries and reached a high point in the refined Flamboyant style of the fifteenth and early sixteenth centuries. ${ }^{7}$ Belgian architectural historians were so proud of their late medieval masterpieces that they defined a style and an architectural school and called it Brabantine 
Gothic (gothique brabançon), after the duchy where the style was prevalent. In the first instance, this style was based on the use of local materials and the art of local architects and craftsmen, and it spread quickly and widely to other parts of the Low Countries. ${ }^{8}$

Because of the importance of this style for the Low Countries, traditional architectural history focused on the question of the origin of Brabantine Gothic at the turn of the fourteenth century. Were its roots French, German, or local? Obviously, after two world wars, that question was a very emotional one, and it was strongly influenced by ideas of national identity. The view historians took of the generation of the year 1300 was clearly retrospective, but their definition of a "Brabantine Gothic School” has only recently been questioned. ${ }^{9}$ In other regions such as Hainaut, Zeeland, Holland, Utrecht, and Liège, only a small number of buildings or parts of buildings dating from around I300 have been preserved. ${ }^{10}$

While German masters from Cologne are recorded in Utrecht and Kampen, two of the most important workshops of the northern Low Countries during the second half of the fourteenth century, ${ }^{11}$ the masters active at the same time in the southern Low Countries seem to have been mostly French. ${ }^{12}$ A medieval transcription of a lost dedication stone mentions that Master Pierre of Savoye began the construction of the choir of the church of St Sulpice in Diest in the year 132I. ${ }^{13}$ The design of this choir with ambulatory and radiating chapels is quite unusual. ${ }^{14}$ Architectural historians have defined the style of Pierre de Savoye as Burgundian and therefore attributed a Burgundian origin to the Brabantine School which developed from the 1340 s onwards. ${ }^{15}$ The name of another French architect is known from a dedication stone in the church of Our Lady in Aarschot: Iacob Piccart (from Picardie) who laid the foundations for the new choir in $1337 .{ }^{16}$ One generation later, shortly after 1350, the names of local master masons are known from several important workshops, like Jan of Osy (from Oisy near Valenciennes in Hainaut) in Tirlemont and Malines, and Adam Gheerijs, the master mason of the Duke of Brabant. ${ }^{17}$

\section{The workshop of the cathedral of Utrecht around 1300}

The cathedral of Utrecht, which housed one of the most important workshops in the Low Countries around I300, underwent successive changes in architectural design. ${ }^{18}$ After a fire in 1253 , a new cathedral was built starting with the radiating chapels, according to a design similar to that of the chapels of the cathedral of Tournai. From around 1300 to 1317 , the aisles of the choir were built on the basis of a changed plan, which is linked to Master Johannes, the new architect of the cathedral of Cologne. In the meantime, another change occurred at the west end of the church. In I32I the bishop decided to construct a huge freestanding tower in front of the Romanesque western facade. It is crowned by a $112 \mathrm{~m}$ high lantern and was built in no less than sixty-one years.

However, the most important changes in the context of this paper occurred in the early fourteenth century. Around 1300 , a radical change occurred in the profile of the sanctuary piers. Instead of round shafts, keeled and filleted mouldings now appeared, accompanied by the suppression of capitals at the springing point of the arches. ${ }^{19}$ One pier shows the transition between the two systems. The change in moulding profiles was combined with a slight enlargement of the choir.

The tower, started in I32I, is built like a belfry and represents the secular power of the bishop, who was also the landlord of extensive territories called the Sticht and the Oversticht. ${ }^{20}$ The lower two levels consist of a passageway through the tower and a chapel on the first floor. The use of superimposed colossal arches instead of buttresses in the corners is borrowed from military building techniques and gives it a powerful, Roman appearance (Fig. I). The lower storeys of tower are built in brick except for the quoins and the gate, which are in stone.

The layout of both the upper levels of the tower and of the unfinished choir and transept were changed again in the 1340s. The splendid lantern of the tower was completed only in 1382 and the clerestory of the choir in the $1380{ }^{21} .^{21}$ Even in the middle of the fifteenth century when work on the cathedral re-started, the nave of the Romanesque cathedral was surviving 


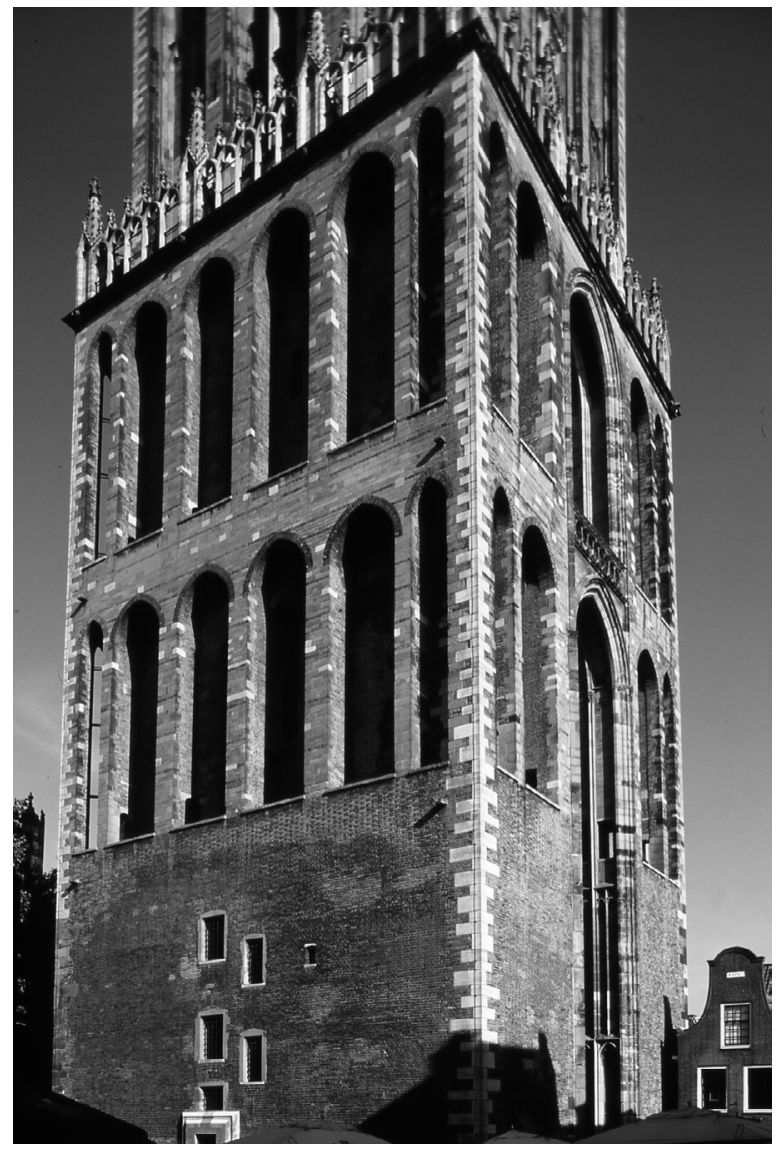

Fig. 1. Tower of Utrecht Cathedral: lower levels from the north-west (THOC, June 2005).

between the two Gothic extremities. Construction finally reached the tower in 1515 .

\section{The new ambitions of princes}

There was no central power in the Low Countries before the fifteenth century and the advent of the rule of the dukes of Burgundy. ${ }^{22}$ Around 1300, the principalities on the borders of the Kingdom of France and the German Empire were at the crossroads of the political ambitions and economic interests of the leading states of continental Europe. After more than a century of political balance, the years around 1300 witnessed a series of important geopolitical changes, resulting from wars and battles, alliances, and marriages. It is worth noting that several reference works on the history of the Low Countries consider the turn of the fourteenth century as a key moment and use it as a break between different volumes of the series. ${ }^{23}$
The battle of the Golden Spurs in 1302, when Flemish citizens defeated the leading knighthood of France, is also considered a milestone in Flanders' history. ${ }^{24}$

One of the principal changes of this period occurred in 1288 when John I, Duke of Brabant, annexed the County of Limbourg after the battle of Woeringen against the Count of Gueldre and the archbishop of Cologne. In I289, after a long war, the count of Holland had succeeded in conquering the western part of Friesland. From 1299, the counts of Hainaut of the Avesnes family also ruled the counties of Holland and Zeeland. The family of Avesnes, the new dynasty of the counts of Hainaut from 1280 , descended from the first marriage of Marguerite of Flanders. The children of Marguerite's second marriage with William of Dampierre founded the new dynasty of the Counts of Flanders, who at that time also had acquired the county of Namur. Between I297 and I3I 4 the king of France, Philip IV the Fair attacked Flanders and tried to annex the lands of his economically most powerful vassal to his crown domains. This war, in which England was indirectly involved - and that prefigured the alliance between Flanders and England during the Hundred Years War - ended only in I3I 4 and caused the loss of Walloon Flanders (Lille, Douai, Orchies). ${ }^{25}$ Count Henry VII of Luxembourg was crowned Roman Emperor in 1308 and his son, the famous John the Blind, count of Luxembourg, became king of Bohemia. Finally, the bishops of Utrecht, Liège, Tournai, and Cambrai were lords and also had secular power.

In short, the princes of the Low Countries had great ambitions for territorial expansion and acquired an international influence broader than ever before. In this changing political landscape, the cities played a crucial role. They provided troops and financed military campaigns in exchange for more liberty and rights. The princes developed new political links with the urban elites, but economic crises pushed the craftsmen and the poor to revolts and "democratic" revolutions in the first half of the fourteenth century, notably in Ypres, Ghent, Bruges, Liège, and Brabant.

The court buildings of the period in question are lost, except one that brilliantly expresses the new ambitions of a prince of that generation. Floris $\mathrm{V}$, count of Holland from 1256 to 1296 , built a new aula in The Hague (Fig. 2). This extraordinary building, with 


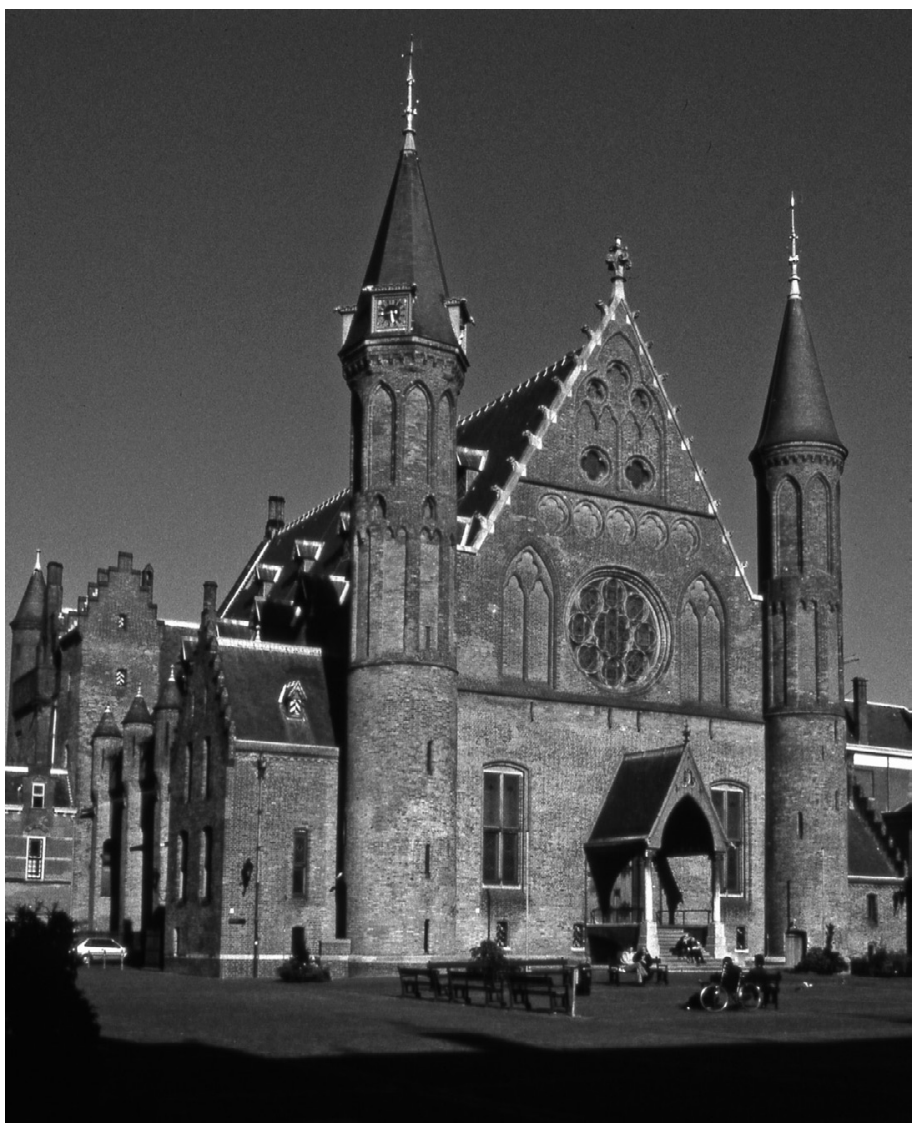

Fig. 2. Great Aula of Floris V in The Hague: western facade (THOC, April 2000).

an inner surface of about 630 square meters (c. $37 \mathrm{~m}$. $x$ c. $17 \mathrm{~m}$ ), and an obviously royal "allure", still stands today in the middle of the Dutch parliament building complex (Fig. 9). Floris's father, William II, had been king of the Romans. Two of Floris's children were married to children of Edward I of England, and Floris himself was one of the claimants to the throne of Scotland in 1290 . He withdrew his claim in 1292 in favour of John Baillol, after having received considerable financial compensation. He invested that money in the building of the aula palatii of The Hague - known as the Ridderzaal - which was intended to express his own royal status: he was the equal of kings. The hall was inaugurated in $1295,{ }^{26}$ but Floris was murdered one year later when he broke his alliance with the king of England and joined the camp of Philip the Fair.

Professor Aart Mekking has interpreted this large building as a combination of an aula referring to Westminster Hall, and a magnificent façade (Schauseite), which includes elements from religious buildings such as the rose-window, and the general silhouette made of gable flanked by two small towers, characteristic of the western front of the cathedral of Salisbury. ${ }^{27}$ This original concept was implemented in brick and timber according to Flemish building techniques. The most remarkable element, as we will see later, is the decoration of the gable with moulded bricks, which, at the end of the thirteenth century, were an innovation.

A totally different kind of political act, in the context of the above mentioned war between Flanders and France (1297-1314), was the construction of a royal castle (koninklijke dwangburcht) by Philip the Fair in the heart of the city of Courtrai. This fortress is partially known from the excavations that have been carried out since $1990 .{ }^{28}$ The castle had a typical polygonal layout and a surface of about 8500 square meters (circa $85 \mathrm{~m} \mathrm{x}$ circa $100 \mathrm{~m}$ ) with round towers at each corner. French military engineers built it in a very short time, between 1300 and 1302 , by using mainly bricks of one format. The location on the bank of the river Lys and in the middle of the comital quarter was both strategic and symbolic. Not only was the new castle facing the old moat of the counts of Flanders, but a polygonal fortified advanced-work that included the collegiate church of Our Lady led into it and thus isolated this comital foundation from the rest of the town. Unfortunately, the castle was dismantled as soon as the French troops left the city and was completely destroyed before the end of the fourteenth century.

\section{Belfries and cloth halls as symbols of new urban autonomy and power}

Besides bishops, canons, and princes, the new patrons also came from the merchant class and the new urban religious orders. The cities of Flanders and Brabant were the first to develop a cloth industry and to import wool on a massive scale from England and Scotland. ${ }^{29}$ Their financial power and the autonomy they acquired from the princes in exchange for supporting their ambitions led to prestigious urban architectural projects. The question of the city walls is not discussed here because work on these was continuous. Around I300, most towns in the Low Countries had stone or brick walls, in some cases dating back well into the twelfth century. In the most populated towns, new 
walls were built around some suburbs, as in Ypres from ${ }_{13} 33^{\text {to }} 1325 / 1328,{ }^{30}$ but it was only from the end of the fourteenth century onwards that the largest towns would build a complete second wall. Around I 300 , the cities also erected new buildings on the main market places such as belfries (belfort), aldermen houses (schepenhuis), and cloth halls (lakenhal).

In Flanders, the power and liberty of the cities was given expression in towers called belfries, in which the seal, keys, and the city's charter of privileges were kept. ${ }^{31}$ In the belfry hung the city's bell or tocsin, which was rung for the opening of the city gates and for all kinds of alarms (fire, troubles, attack, etc.). The battlements that topped the towers and walls did not have any military role but were symbols of vigilance and guardianship. The belfry of Tournai is considered to be the oldest one. ${ }^{32}$ The lower levels were built soon after Philippe Auguste had given the city its liberty in II 80 , but the original tower was reinforced in 1294 and heightened in 1396. Situated less than room from the cathedral, it expressed the city's independece from the bishop.

The belfry of Ghent, which originally was a freestanding tower, was erected from around 1300 to 1376. An exceptional early fourteenth-century drawing on parchment $(2,25 \mathrm{~m}$ high) survives which shows an unrealised project with different proportions, Rayonnant traceries, decorations, and a complete programme for painting the outer walls consisting of false joints imitating regular masonry and a frieze with figurative wall paintings. ${ }^{33}$ The present upper level and the spire of the belfry date from the World Exhibition of Ghent in 1913 and replace a previous spire of the early 1850 s. A cloth hall was added on the eastern side of the belfry in the fifteenth century.

In other cities belfries were planned in combination with cloth halls. The most remarkable hall complex with a belfry can be found in Ypres. ${ }^{34}$ It was reconstructed after having been almost totally destroyed during the First World War (Fig. 3). Construction of the eastern wing of the hall was started around 1260. Work on the western and back wings progressed in I286. The whole complex was completed in 1304 , but we know from various accounts that the façades were painted in 1330 with white, green, vermilion, and ochre colours enhanced with gold leaf. With a total length

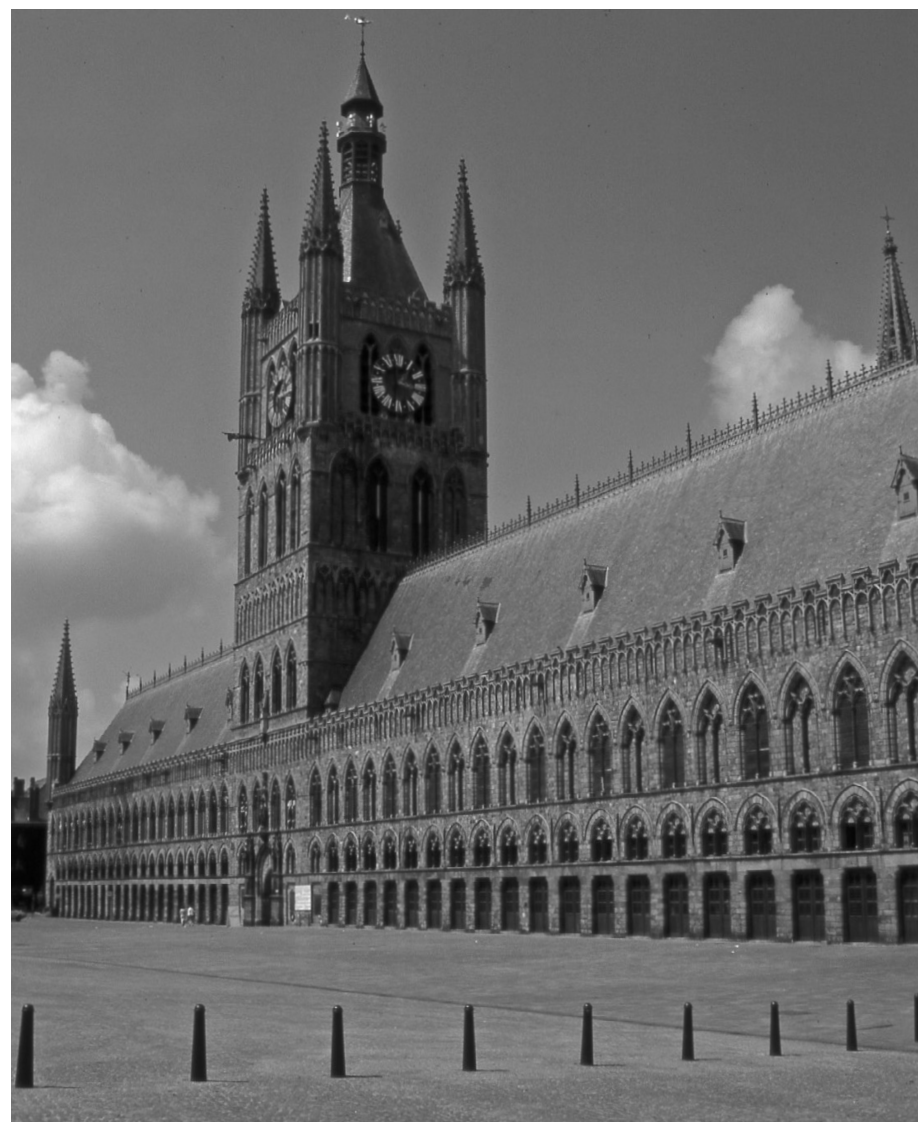

Fig. 3. Cloth hall and belfry in Ypres: south façade facing the market place (THOC, July 1997).

of $133 \mathrm{~m}$, the hall of Ypres is considered to be the largest civic building ever built in the Middle Ages. A canal entered the hall at the back, so that small ships could load and unload cargo inside the hall. All the openings at the lower levels led into small shops that connected with the public space of the market place. The stone façades had no sculptural decoration, but the size of the building was emphasised by crenellations on top of the walls and colossal turrets on the corners of the hall and the belfry. Inside, the hall is a succession of huge covered spaces. A ceiling supported by a central row of columns covers the ground level, while the upper floor is spanned by the wooden beam structure of the roof. There are no stone vaults except in the passageway traversing the belfry at ground level (Fig. 9).

The belfry and cloth hall of Bruges are of similar design with two-storied wings, an inner courtyard, and a tower in the middle of the northern wall on the market side. ${ }^{35}$ (Fig. 9) A first hall may have been built 
around I240, but we know that an earlier wooden belfry burned out in 1280 . Recent tree-ring analysis dated the timber of the western wing after 1268 , that of the eastern wing to between I28I and I29I, and that of the southern wing to between 1270 and $1300 .{ }^{36}$ It seems thus that the cloth hall was entirely rebuilt after the fire of 1280 and that the western wing is the most recent. The tower was heightened around 1345 when the present middle part was built, and the upper octagonal storey was added in I482-I486. These changes prove how important a belfry was for the identity of the city. Clearly, the citizens did not hesitate to "update" the tower's silhouette in order to strengthen its symbolic meaning. In contrast to Ypres, the masonry was essentially made of brick and the outer walls were decorated with brick arches, cantilevers, and crenellations.

On the eastern side of the market place in Bruges was a water hall (waterballe), ${ }^{37}$ a longitudinal hall built upon a canal and accessible to small ships from the two short sides. The accounts of the city mention that the water hall was built in 1283-1294 and that shops were added between the buttresses on the market side in the years $1332-1337$. The hall, about $95 \mathrm{~m}$ long and $25 \mathrm{~m}$ wide, had two levels. The lower level for the ships was divided into two aisles by a row of twelve columns standing in the water and supporting a wooden floor in which there were openings. The upper level of the hall was one huge space covered with a timber structure without any central support. Unfortunately, the water hall was destroyed at the end of the eighteenth century and therefore the unique juxtaposition of the water hall, the cloth hall, and the belfry on the market place of Bruges, which contributed to the economic and visual power of the medieval city, is lost.

Thanks to two dedication stones on the outer wall of the cloth hall of Louvain, we know that its construction began in 1317 and was led by the masters Jean Stevens, Arnould Hore, and Godefroid Raes. ${ }^{38}$ The hall, which was badly damaged in 1914, is divided into two aisles by a row of columns supporting round arches (Fig. 9) and has a surface of about 1280 square meters (2Im x $6 \mathrm{Im})$. The walls are made of local sandstone and are decorated with delicately carved niches and elongated figures, which are typical of early fourteenth-century sculpture in Brabant. Originally, small doors opened to the street on the four sides of the building, as in Bruges and Ypres. The Lakenhuys of Diest, dated 1346 by a dedication stone, is of the same type as that of Louvain, with a central row of columns and round arches supporting a wooden floor. Other cloth halls of the first half of the fourteenth century are partially conserved in Brabant and Flanders, such as the cloth hall of Malines, enlarged in $131 \mathrm{I}-1326,{ }^{39}$ the hall of Léau (Zoutleeuw), built after 1316, the cloth hall of Dendermonde, built in 1337 and flanked with a belfry in 1377, the single aisled cloth hall of Audenarde, which is not yet accurately dated, and the hall, now demolished, that stood next to the belfry in the middle of the market place in Courtrai.

No town halls of the generation of 1300 have survived in the Low Countries. Most of them were built or rebuilt in the more prosperous fifteenth and sixteenth centuries, but some include early fourteenthcentury walls and cellars. Such remains are to be found in the town hall of Goes in Zeeland, Delft in Holland (a tower and prison of the count), and Utrecht, as well as in the town halls of the Hanseatic cities of Deventer, Zutphen, Kampen, and Zwolle, all four situated along the Ijssel river.

\section{Hospitals}

By the end of the twelfth century, merchant families had founded hospitals and separate leper-houses on the outskirts of all the important cities; half a century later, hospitals could be found within the walls of all the major towns. ${ }^{40}$ Religious communities of women served the hospitals from their foundation, in accordance with the statutes of their institutions, almost always based on the rule of St Augustine. These specialised hospital communities were part of new socioreligious developments in the cities. In the following centuries, smaller institutions for old people, orphans, lepers, etc. were founded besides hospitals.

Hospitals and cloth halls, two of the new types of buildings in the growing merchant town, had similar functional layouts, they were also built with brick and timber, and they were sponsored by the same patrons. Medieval hospital buildings rarely survive, but four hospitals of the second half of the thirteenth century are preserved in Flanders. They are mentioned in all the histories of hospital architecture but, until now, 


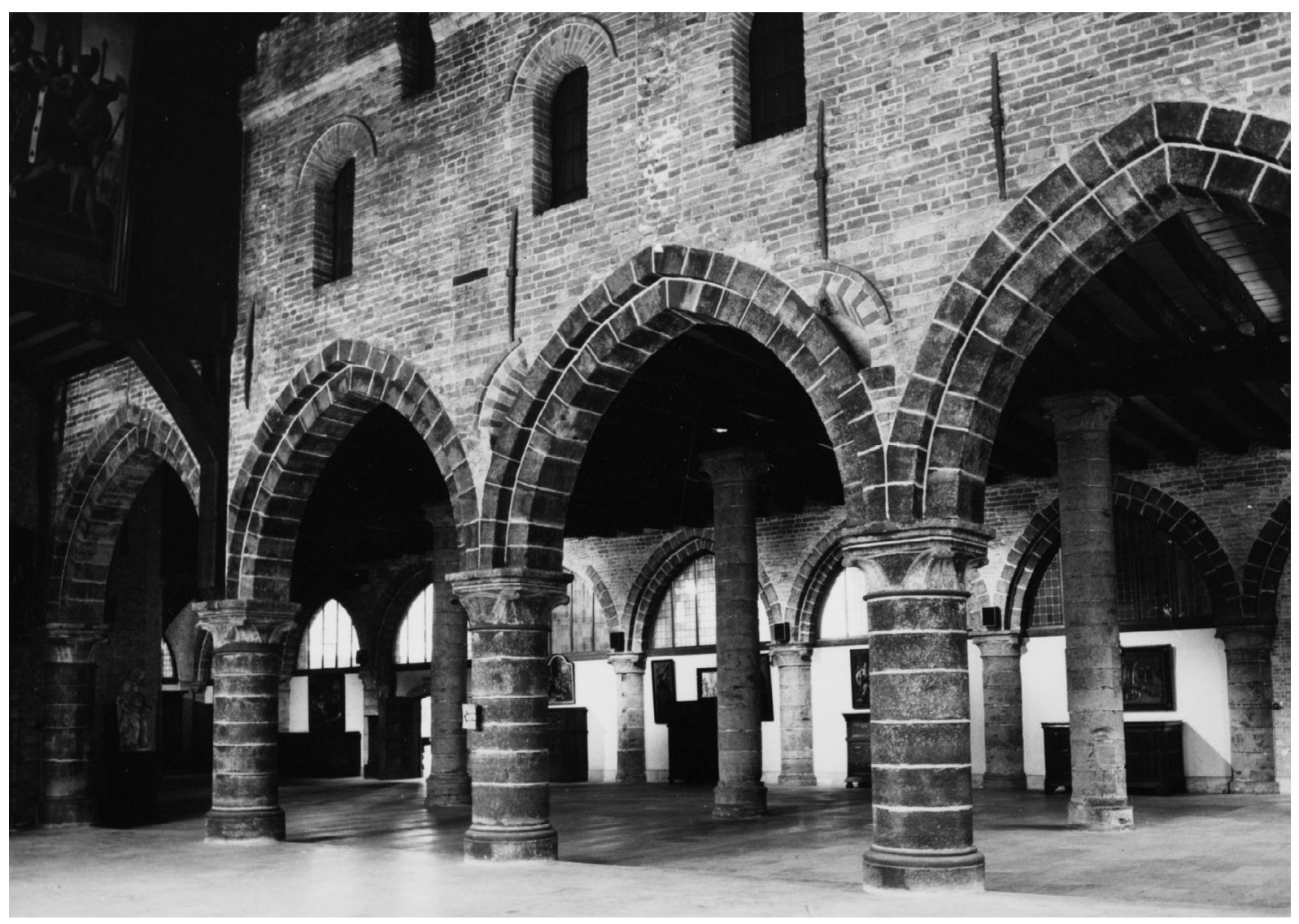

Fig. 4. St John's Hospital in Bruges: sick ward from the north (Stedelijke musea Brugge, André Deblieck, 1975).

they have been inaccurately dated. ${ }^{41}$ Recent tree-ring analysis, that allows us to pinpoint building dates more precisely, shows that the main halls of the four hospitals belong to the period considered here. ${ }^{42}$ The oldest, and also one of the finest medieval examples of European hospital architecture, is the great hall of the Bijloke Hospital in Ghent. ${ }^{43}$ It occupies a space of 867 square meters ( $55.10 \mathrm{~m} \times 15.75 \mathrm{~m}$ ) and is the main building of a complex that includes a chapel and more halls, added at a later date. Tree-ring analysis has dated the unique trefoiled timberwork to the years I25I-1255. ${ }^{44}$

Another major example of medieval hospital architecture is St John's Hospital in Bruges. It was founded in the middle of the twelfth century and its sick ward was successively enlarged ${ }^{45}$ Segments were added over the next two centuries until the chapel occupied only one corner of an open space of about 1500 square meters (Fig. 9). The central vessel is tree-ring dated to between 1226 and 124I, the northern aisle with the chapel and the tower to about 1268 , and the large southern aisle to about $1285 .{ }^{46}$ The hospital is a functional building made of brick and timber and has no decoration at all. The tall windows generously illuminate the ward on the eastern and southern sides, in accordance with the theories of Galen and Hippocrates. The latrine blocks are situated on the canal side. Like the cloth halls, St John's Hospital is divided into two storeys. On the ground-floor, rows of columns and posts divide the ward into five aisles, added in diffirent campaigns (Fig. 4). The wooden posts belong to the late thirteenth-century extension phase. On the upper level, which was later used by the hospital used as a dormitory, each nave is covered with a separate saddle roof.

Two smaller hospital buildings of the last quarter of the thirteenth century survive in Flanders. The Poterie Hospital in Bruges ${ }^{47}$ built on the opposite side of the city from St John's Hospital, has a nave consisting of two parallel aisles and a chapel but no first-floor. Recent tree-ring analysis has dated the timber of the 


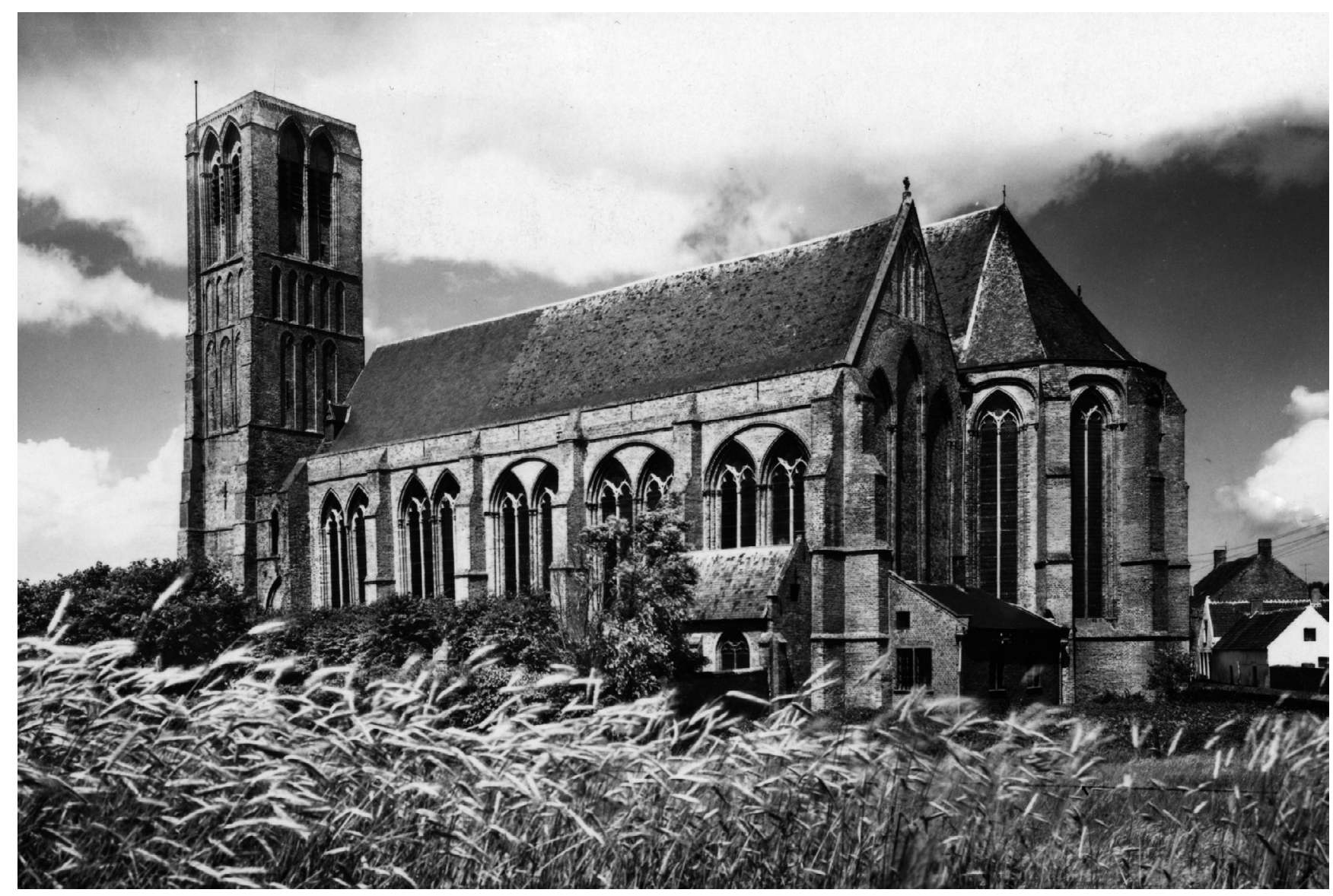

Fig. 5. Church of Our Lady in Damme: hall choir from the south-east (Nels postcards, around 1950).

main ward to the years 1276-I296. In St John's Hospital in Damme, ${ }^{48}$ the sick ward on the ground floor was covered with a ceiling supported by a central row of columns, while the upper floor housed the dormitory of the hospital sisters. The timber was also recently dated by tree-ring analysis to the years I270-I285.

\section{The first hall churches}

It is not surprising that some urban churches adopted similar hall structures when they had to be rapidly enlarged to accommodate the growing number of churchgoers. The building phases of the church of Our Lady in Damme show how the idea of the hall was gradually applied to church construction during the second half of the thirteenth century. ${ }^{49}$ Originally, the church, built during the second quarter of the thirteenth century, was composed of a western tower, an aisled basilican nave of two bays, a large transept, and a choir of two bays with an apse. The first enlargement took place during the second half of the thirteenth century, and consisted of flanking the existing choir with two chapels as high and deep as the choir itself and as wide as the transept. The chapels were open to the sanctuary and illuminated by large windows in the side walls, thus creating the first "hall choir" (Fig. 9). The second enlargement occurred in the early years of the fourteenth century and consisted of extending the hall choir by adding three new bays to the east (Fig. 5). In its final configuration, the hall choir, seven bays long and entirely built of bricks, was covered with three parallel wooden barrel vaults resting on two rows of columns and arches. Only the central vessel of the choir has a polygonal apse while the two side vessels end with a straight eastern wall. When Damme was reduced to a village, the nave was abandoned and, in the eighteenth century, it fell into ruins. 
A similar process of enlarging a choir with tall side chapels had already taken place in the church of St Brice in Tournai around I225; later, in the early fifteenth century, this hall choir was lengthened by adding two more bays. ${ }^{50}$ The choir of St. Walburgh in Audenarde is another example of an early hall structure created before the end of the thirteenth century by flanking the choir with chapels of the same height as the choir itself. ${ }^{51}$

Thus, the Flemish hall church was first conceived during the process of enlarging older buildings. However, shortly before 1300 , the hall type structure was adopted for new churches from the start of the construction, because it was spacious and bright. It was also economical, not only because of the use of brick and timber - the cheapest building materials in areas without stone quarries - but also because it was a simple, standardised structure that did not require brick vaulting. Amongst the earliest three-vessel hall structures are the nave of Our Lady in Poperinge (from I290), the nave and the choir of the St Martin in Courtrai, and the choir of Our Lady in Nieuwpoort (early fourteenth century). ${ }^{52}$ Brick and timber hall churches flourished from the middle of the fourteenth century until the early sixteenth century in the coastal areas, from French Flanders to Zeeland, Holland, and Friesland, ${ }^{53}$ as well as in other parts of the Low Countries such as Hainaut, Gueldre, and Utrecht. Nonetheless, many of the major churches in the cities of the Low Countries were originally basilican structures that have subsequently been enlarged and converted into hall-churches. ${ }^{54}$

\section{The churches of the mendicants}

In the thirteenth century, urban society attracted new religious orders, such as the mendicant orders of the Dominicans, Franciscans, Augustinians collegiate and Carmelites. In the Low Countries, as many as seventy male convents of mendicants were founded between the 1220 and 1330 . Around 1300 the four mendicant orders had houses in Bruges, Ghent, Ypres, Haarlem, and Liège. ${ }^{55}$ Because of the opposition of the collegiate chapters and the parish churches, who considered the friars as rivals, establishing mendicant houses inside the towns was often a complex process.

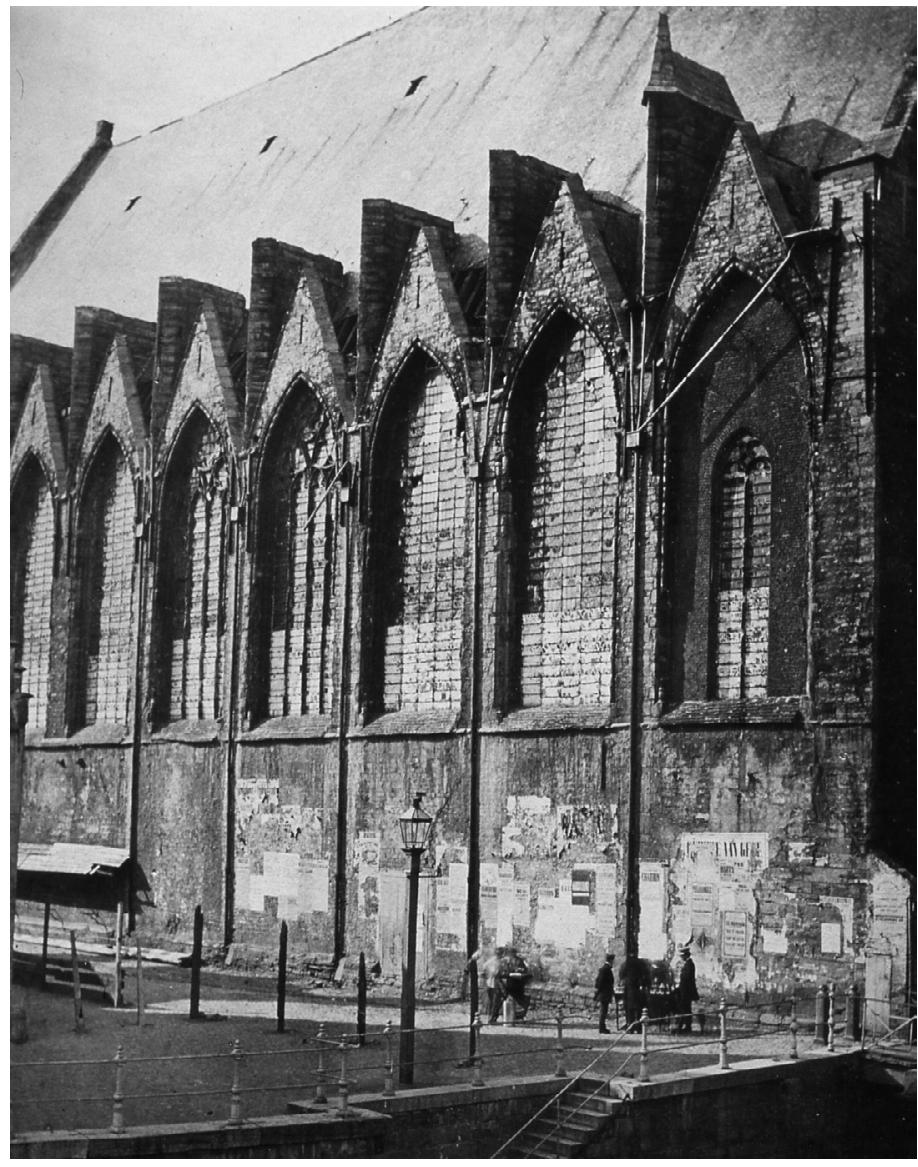

Fig. 6. Church of the Dominicans in Ghent: southern wall before 1860 (KULeuven-KADOC, Archief Sint-Lukas Gent).

The mendicants developed new types of churches in accordance with their apostolate and their distinct identity. ${ }^{56}$ One of the most remarkable mendicant churches in the Low Countries was the church of the Dominicans in Ghent, built between about 1260 and I290, but unfortunately demolished in $1860 .{ }^{57}$ It was a huge single aisled hall, on a rectangular plan with an area of about 1224 square meters $(5 \mathrm{Im} \mathrm{x} 24 \mathrm{~m})$, and it was perfectly integrated into the urban structures of the city centre (Fig. 9). The wooden barrel vault was 29 meters high and had a span of 16 meters. The buttresses were drawn inside the church and strengthened with arches above the high windows. Thus, the outer walls were completely flat and opened up with large tracery windows under the gables (Fig. 6). The modernity of this church was remarkable: no apse, no transept, no aisles, no tower, no architectural distinction between choir and nave, just a brightly lit, unified space, destined for worship, devotion, and preaching. 
Nevertheless, most of the mendicant churches built during the second half of the thirteenth century adopted a different layout, consisting of a basilican nave and a choir ultimately derived from the SainteChapelle in Paris. The choir of the Dominican church in Louvain was built on the site of the palace of the dukes of Brabant, as a burial church for duke Henri III who died in 126r. The splendid 7/12 apse with explicit royal references introduced a totally new architecture to Louvain, radically breaking with existing types of church architecture. ${ }^{58}$ The nave was built during the first half of the fourteenth century according to a much more modest design, since the dukes had moved their capital to Brussels and no longer supported the institution. This part of the church, designed for preaching, has a reduced clerestory and is covered with a wooden barrel vault.

The Franciscan church of Maastricht was also built in two phases. ${ }^{59}$ Here, the reference to the Minoritenkirche of Cologne, the capital of the Franciscan province, is clearly evident. The choir with its beautiful apse consisting of five sides of a decsgon ( $5 / 10)$ and a semi-quadripartite straight bay was built around 1305 , while the western part of the church dates from the I390s. Like most of the mendicant churches of its generation, the Franciscan church of Maastricht has neither a transept, nor a tower, nor decorated portals. In comparison with the church of Louvain, the differences are in the building materials - always local but without any real effect on the architectural concept - and the traceries. The traceries at Maastricht are more Rayonnant and they cover the whole of the triforium zone, which, in that way, is integrated with the clerestory and gives the general impression of a twostorey elevation. Unfortunately, we have no indication how and in what colour the walls were painted, unlike the Dominican church in the same town. That church was also built in two main phases: first the choir was built between 1276 and 1277 , dated by tree-ring analysis, and dedicated in 1294 ; later the four western bays of the nave were roofed with wood that was cut in the years 1392-I 437. Architectural comparisons and chronological parallels reveal evidence of competition between the two mendicant orders, and it is clear that for each community the singularity of their church was part of their identity. ${ }^{60}$
The Dominican church in Zutphen (Gueldre) was built in the early fourteenth century. The date is known from an archival mention of toll-exemptions for the transport of building materials on the Rhine, dated 1306. ${ }^{61}$ The plan and the basilican elevation of the church are similar to the mendicant churches of Maastricht and Louvain. The main difference is the use of brick as a building material, which is also used for the vaults and the flying buttresses. The decoration is limited to blind brick traceries at triforium level and at the top of the main gable. The only sculpted elements are the roughly carved capitals of the nave, and the corbels of the choir. The mendicant aesthetic generally favoured proportion and light over architectural ornament and certainly over figurative decorations.

When churches became too small, their naves were sometimes lengthened. In other cases new side aisles were added to the existing nave, resulting in hall structures similar to hospital wards. ${ }^{62}$. The timber of the Carmelite church of Ghent has been accurately dated by tree-ring analysis, and reveals an interesting sequence of campaigns to enlarge the church, extending into the early sixteenth century. ${ }^{63}$ This phenomenon was common in Flanders, Holland, and Zeeland. The Carmelite church of Ghent has a fine brick decoration on its western gable, which belongs to the first phase of about 1325 .

\section{Beguinages}

Each town of the Low Countries had one or several Beguinages. ${ }^{64}$ Beguines were semi-religious women living a communal life, a hitherto unknown type of community. The origin of the movement goes back to the first years of the thirteenth century, and to the bishopric of Liège, and it climaxed in the years I240I280. The Church hierarchy controlled this womens movement by asking the Dominican and Franciscan friars to be its spiritual directors and by requesting the cities to build enclosed quarters for the communities, generally outside the city walls. In the early years of the movement, Beguines often worked in hospitals; later they were more strictly enclosed. In I3II, the council of Vienne, accused the Beguines of heresy and submitted them to the Inquisition. That was to be fatal for the Beguine movement, except in the Low Countries where the bishops protected them. 
A small number of medieval Beguinage churches survive in the Low Countries. The most representative is the church of St John the Baptist in the Beguinage of Louvain. We know from a dedication stone that construction started in $1305 .{ }^{65}$ The plan of the church consists of a rectangular area of 1566 square meters $(54 \mathrm{~m} \times 29 \mathrm{~m})$, divided by two rows of ten columns into a central vessel flanked by two low aisles (Fig. 9). This rectangular plan is so simple that it could be that of a hospital or a barn; nevertheless, a huge window with Rayonnant tracery illuminates the choir and immediately identifies the building as a church (Fig. 7). The church was built in two main phases: first, from 1305 , the seven eastern bays; later, in I42I-I 444, the three western bays were added. Brick vaults were erected in the seventeenth century and the interior was re-furnished in the Baroque style. But above the vaults, the original wooden structure of the roof is still preserved, and reveals that the original space was much higher. This simple structure was similar to that of the nave of the Dominicans in Louvain, which also dates from the first decades of the fourteenth century. ${ }^{66}$

Three other churches of Beguinages in the diocese of Liège constitute a homogenous group of small and "poor" churches, with timber vaulting recently dated by tree-ring analysis. ${ }^{67}$ The church of St Catherine in the Beguinage of Tongres was built from 1263 to I28I, and side chapels were added to the first bay of the nave in I291-1305, forming a transept. The basilican nave of St Catherine's church in the Beguinage of Diest dates from the years $1284-1304$, while the transept and the choir were built between I32I and 1345. The church of St Agnes in the Beguinage of St Trond has a complex building history, with one of the phases (the heightening of the choir) dating to around 1300 . The ruined church of Our Lady of the Beguinage of Tirlemont also has a choir from the early fourteenth century.

In short, the churches of the Beguines adopted a very simple layout, timber vaulting and eschewed architectural decoration. The columns are cylindrical and smooth, the mouldings are limited, and the capitals minimal, as in a cloth hall or a hospital ward. Around 1300 , the churches of the Beguines, more than those of the Mendicant friars, expressed a sense of humility and poverty that was both religious and apostolic, and was inspired by the life of the first Christian communities as described in the Acts of the Apostles. ${ }^{68}$

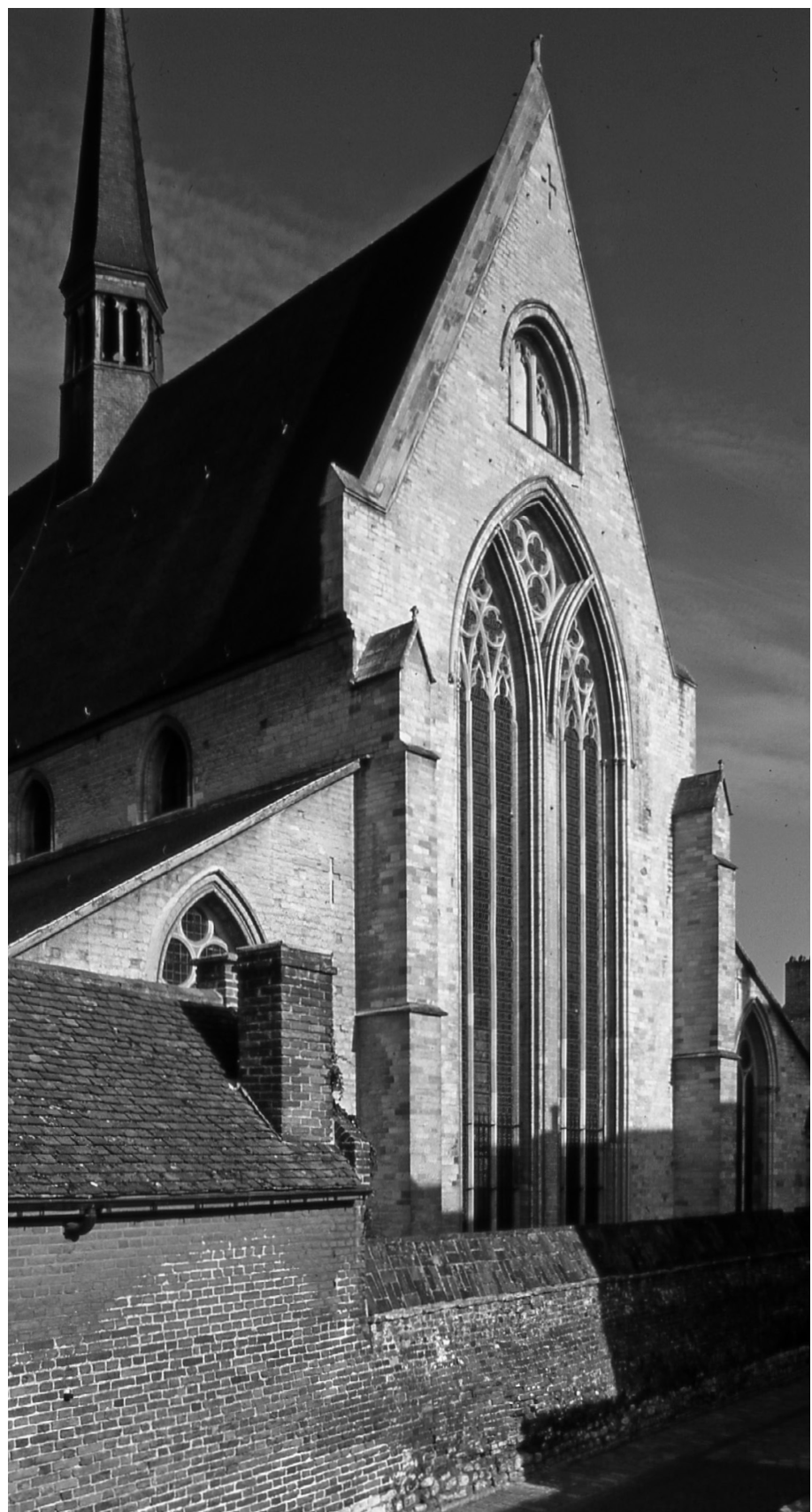

Fig. 7. Beguinage church in Louvain: chevet from the south-east (THOC, July 2003).

For its adherents this ideal implied a clearly identifiable code of behaviour that expressed itself in the communal life, the financial precariousness of the institutions (begging), the dress (habits of rough cloth), the food (vegetarianism), etc., but also in distinct architectural and aesthetic choices. 


\section{The spread of brick architecture}

Most buildings we have so far considered were built in brick, including the hall of Floris V in The Hague, the castle of Philip the Fair in Courtrai, the cloth hall and St John's Hospital in Bruges, the tower of the cathedral of Utrecht, the hall church and the hospital ward in Damme, etc. Shaped into moulded and standardised elements, brick became the ideal material for the increasing building activities in the most urbanised parts of the Low Countries.

Brick had been introduced in the Low Countries at the end of the twelfth century and its use spread quickly into the growing urban areas. Flanders, Zeeland, Holland, Utrecht, and Friesland, the coastal regions, had no stone quarries and very limited resources of wood, but were rich in good clay for brick and tile production. ${ }^{69}$ The use of stone, which was expensive because it had to be imported, was limited to carved decorative elements and outer facings in exceptional buildings. In Brabant, local stone was combined with brick from the end of the thirteenth century. The area south of Antwerp, which was rich in good clay, also produced brick on a huge scale. Thus, at the end of the thirteenth century, brick production had become a real industry and brick was exported particularly to England. "Most of the bricks used in England before the second quarter of the fourteenth century seem to have been imported from the Low Countries. Enormous quantities of Flemish bricks were used at the Tower [of London] in 1278 (...). During the whole of the fourteenth century, Flemish tiles figure among the imports of the eastern ports" ${ }^{70}$

However, from around 1300, the brick moulds were reduced in size, both because small bricks could be made more quickly and cheaply, and because small bricks were less likely to burst or warp in the high temperatures reached in the big brick kilns. ${ }^{71}$ Smaller bricks were also easier to transport and to manipulate in the workshop. This significant change of size - from c. $32 / 35 \times 15,5 / 17 \times 9 / 1$ Icm (the kloostermop) to circa 28 $\mathrm{X} 13 \times 6 \mathrm{~cm}-$ allowed the masons to work in a new way: from then on they were able to hold a brick in one hand and a trowel in the other, and thus work more quickly. Another consequence was a change in the masonry's bond: the "Flemish bond" or "Gothic bond" (each layer consisting of an alternation of stretchers and headers) was abandoned in the early fourteenth century for the "English bond" (one layer of headers alternating with one layer of stretchers).

From the fourth quarter of the thirteenth century, brick production had assimilated decorative forms of the Rayonnant style and a variety of bricks with elaborate profiles were developed. This evolution was widespread and also occurred in Denmark, Northern Germany, and Poland, the other brick areas of Northern Europe. ${ }^{72}$ In the Netherlands, the prestigious main front of the hall of Floris V in The Hague, which was inaugurated in I295, with its large trefoil niche, its blind tracery and its quatrefoiled oculus (Fig. 2), became a model for several other buildings, including the tower of the Cistercian convent of Loosduinen (around 1300), the upper part of the tower of the St Jeroen church in Noordwijk (circa 1303), and the right chevet of the church in Abbebroek (circa I300). It is not impossible that the use of these decorative motifs was considered an indication of comital identity. ${ }^{73}$

The refectory wing of the Cistercian convent of Bijloke in Ghent, built in the 1320 s, is one of the most refined buildings of its generation and a masterpiece of brick architecture (Fig. 8). ${ }^{74}$ The convent was linked to a hospital and was patronised by the counts of Flanders as well as by the city's merchant families. The architecture and the decoration of the refectory demonstrate that not all the urban religious communities adopted the same "poor" architectural aesthetic which was prevalent among the mendicants and the Beguines, and that architecture was intended to reflect the prestige, social standing, and complex political links of the communities. The refectory occupies the first floor above the kitchen and the cellars. The room is illuminated from three sides and is covered with a high, wooden barrel vault. Some elements of the polychromy and a painted Last Supper are original. But the most extraordinary aspect of the convent is the complex geometric decoration of the western gable, which was made of moulded bricks. The refectory of Bijloke, built thirty years after the great aula of The Hague, is a building of the very end of the generation of the year I300. 


\section{Space as an expression of power}

Clearly, around the year 1300, Flanders and its rich cities had a leading position in the Low Countries and constituted one of the most dynamic areas in Europe. Flanders aroused the interest of Philip the Fair, who nevertheless did not succeed in annexing the county. At the Battle of the Golden Spurs in 1302, Flemish citizens defeated the flower of he French chivalry. Henceforth, the princes had to deal with the new class of merchants, who themselves had to maintain their authority over the working-class and the poor. Religious orders developed a new apostolic mission and worked for social peace. One can imagine how attractive such cities were for all kinds of people, and how complex the social problems were. Never before had cities been as large and as densely populated. Major social upheavals, resulting from industrial changes in the textile trade, ${ }^{75}$ were common from the late thirteenth century onwards, as for example the "democratic revolts" in Ypres, Bruges, Ghent, Liège, and several towns in Brabant. ${ }^{76}$

The rationalisation of building techniques and the massive use of brick combined with carpentry made it possible to build quickly and to erect huge halls with different functions, whether for trade, worship, or health care (Fig. 9). Great halls in palatial complexes, like that of Floris V in The Hague, expressed the power of kings and princes. In the urban context, spacious halls were linked with another kind of power, of which the combination of a belfry and a cloth hall is the best architectural expression. The tower, a symbol of liberty, together with the hall, a covered space for exhibiting and selling the city's best products throughout the whole year, made the hall the vital heart of the merchant town.

Public architecture always materializes the needs and ideals of a growing urban society at a precise moment in its expansion. The architecture around the

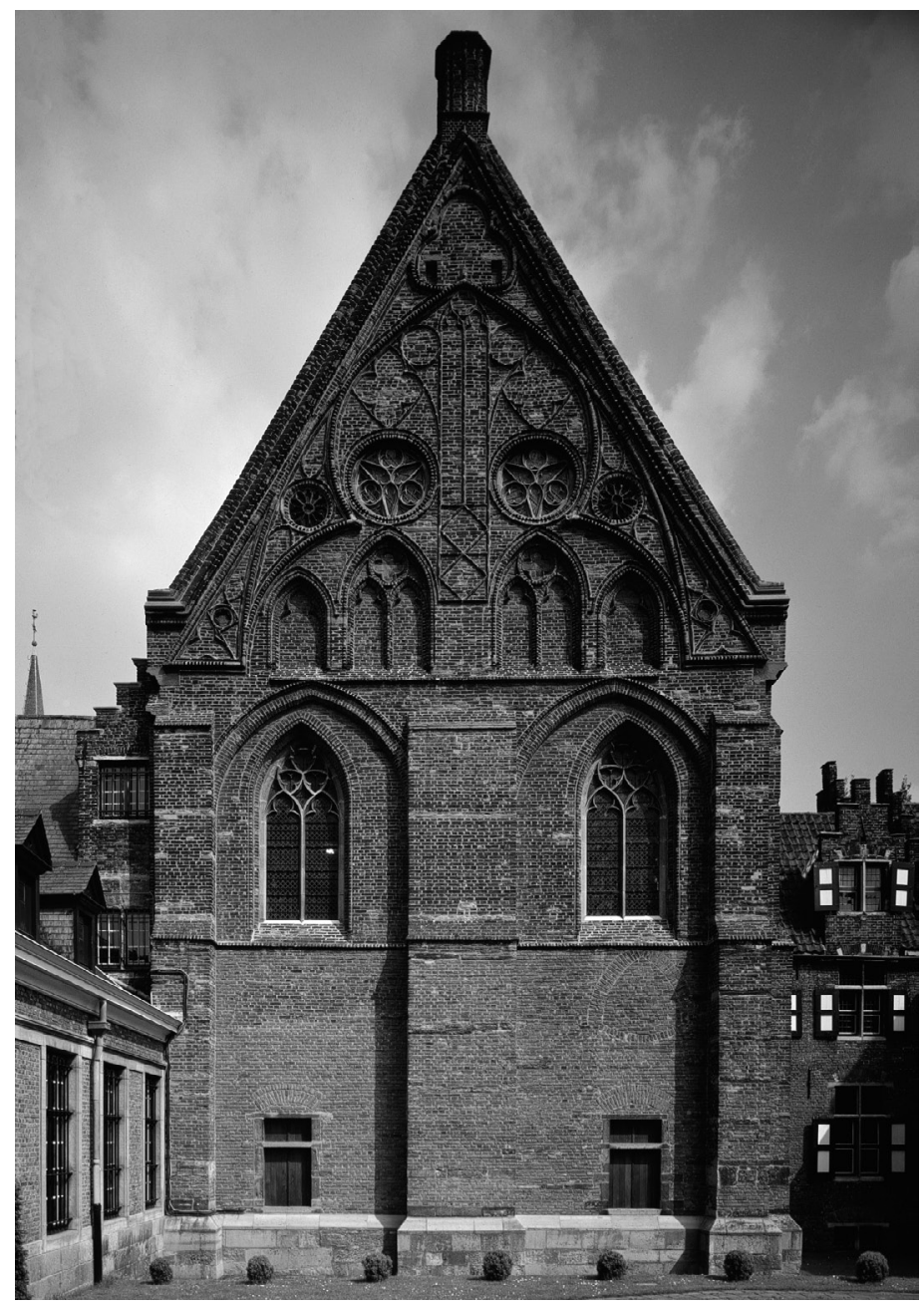

Fig. 8. Bijloke nunnery in Ghent: western gable of the refectory wing (Vlaams Instituut voor Onroerend Erfgoed, Oswald Pauwels, 1997).

year 1300 developed a functional diversity and opened Gothic architecture to new formal systems. Belfries and cloth halls, as well as hospitals and mendicant churches are the most emblematic buildings of the Gothic town in the Low Countries before the onset of the Black Death. 


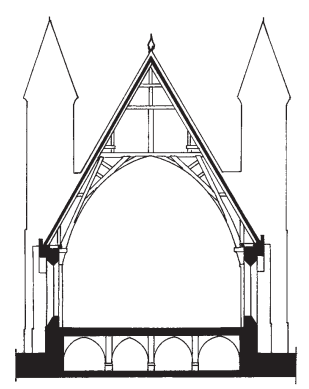

A
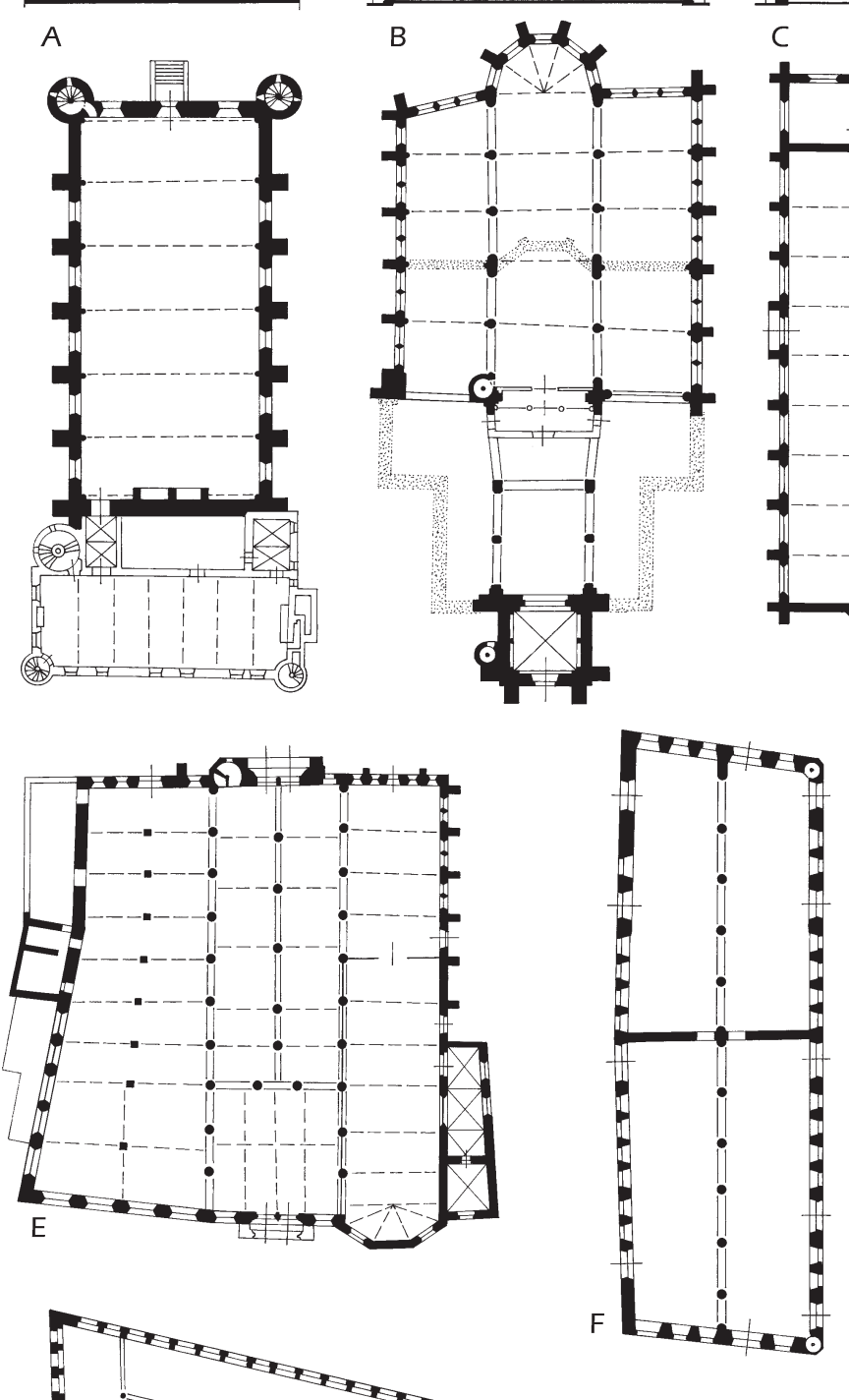
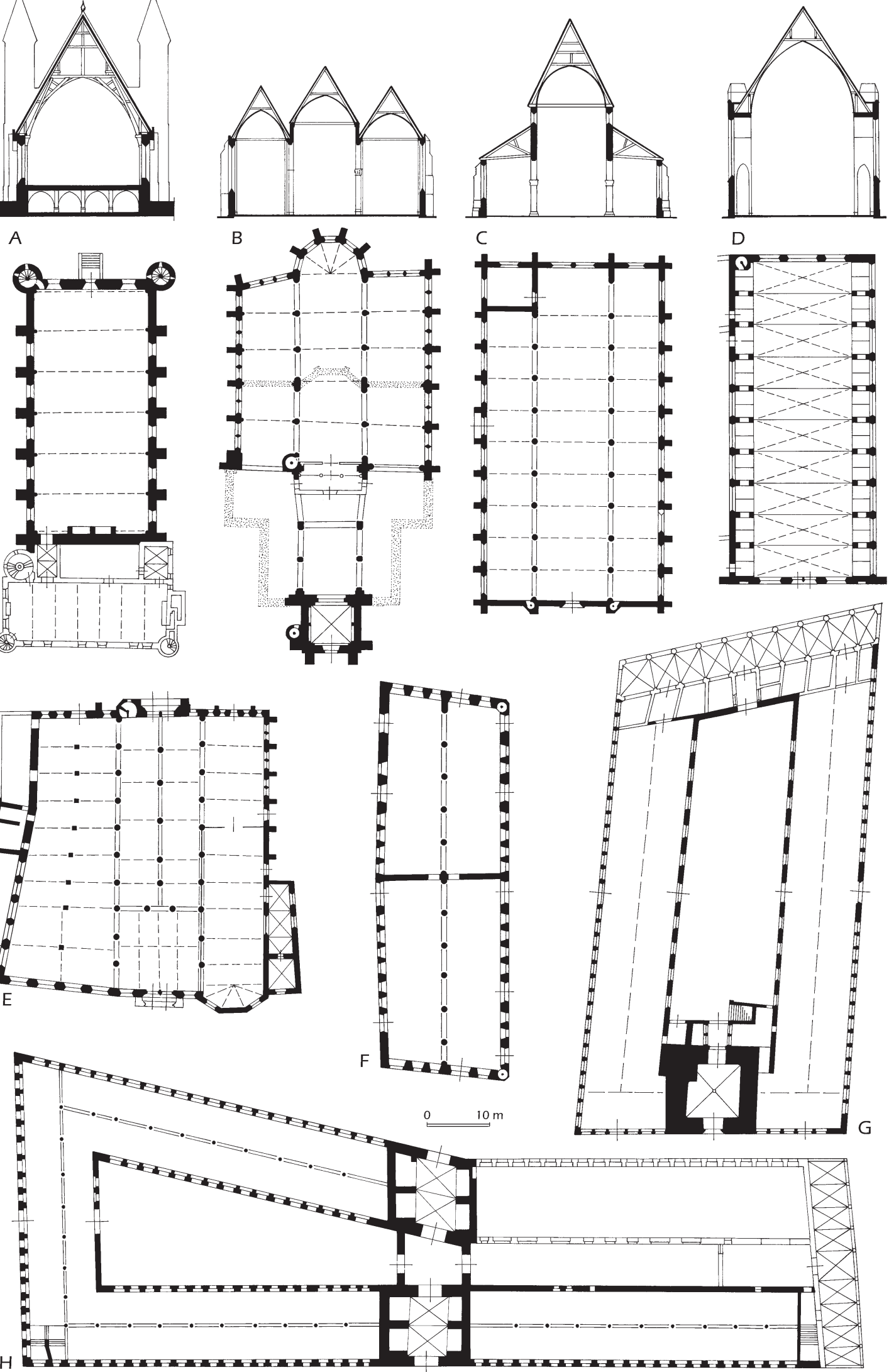


\section{NOTES}

${ }^{1}$ It is a pleasure for me to express my gratitude to Paul Crossley, Zoë Opačić, Alexandra Gajewski, Aart Mekking, Wim Blockmans, Patrick Hoffsummer, Jerôme Eeckhout, Dirk Van Eenhooge, Dirk Jan de Vries, Karel Emmens, Vincent Debonne, Anna Bergmans, Maria Kelly, Marie Christine Laleman and Véronique Cardon for their interest and assistance in the course of my research. 2 The oldest known building regulation in the Low Countries concerned the covering of roofs in the town of Aardenburg and dates from I232. Willy P. Dezutter \& Marc J. Ryckaert, "Een stedelijk bouwvoorschrift uit 1232 tegen brandgevaar (Aardenburg en Brugge)", in Willy P. Dezutter \& M. Goetinck (ed.), Op en om de bouwwerf. Ambachtswezen, oud gereedschap, Bruges, 1975, p. 59-67.

${ }^{3}$ With some exceptions: A.L.J. VAN DE WALle, "Excavations in the Ancient Centre of Antwerp", in Medieval Archaeology, 1961, 5, p. 123-136; Marie Christine Laleman \& Patrick Raveschot, Inleiding tot de studie van de woonhuizen in Gent. Periode IIoo-I300. De kelders (Verhandelingen van de Koninklijke Academie voor wetenschappen, letteren en schone kunsten van België), Brussels, I99I; Marc Dewilde \& Stephan Van Bellingen, "Excavating a Suburb of Medieval Ypres (Belgium). Evidence for the Cloth Industry?", in Marc Dewilde, Anton ERvynck \& Alexis WieleMans (ed.), Ypres and the Medieval Cloth Industry in Flanders. Archaeological and Historical Contributions (Archeologie in Vlaanderen. Monografie, 2), Asse-Zellik, 1998, p. 57-76.

${ }^{4}$ David Nicholas, Urban Europe, IIoo-I700, Bristol, 2003, p. 26.

${ }^{5}$ The most recent works on Gothic architecture in Belgium and the Netherlands are: Marjan Buyle, Thomas Coomans, Jan Esther \& Luc Francis Genicot, L'architecture gothique en Belgique, Brussels, 1997; Koos Bosma, Aart J.J. Mekring, Koen OtTENheym \& Auke VAN DER Woud (ed.), Bouwen in Nederland 600-2000, Zwolle, 2007 (p. 106-229). See also earlier publications: Adelbrecht L.J. VAN DE WALLE, Belgique gothique: architecture, art monumental, Brussels, 1971; Sybr J. Fockema AndREA, Engelbert H. Ter Kuile \& Robert C. Hekker, Duizend jaar bouwen in Nederland, vol. I, De bouwkunst van de Middeleeuwen, Amsterdam, 1957.

${ }^{6}$ There are several contributions in: Benoît VAN DEN BossChE (ed.), La cathédrale gothique Saint-Lambert à Liège: une église et son contexte. Actes du colloque international tenu du I6 au I8 avril 2002 (Études et recherches archéologiques de l'Université de Liège, I08), Liège, 2005; see, amongst others, Jeroen WeSTERMAN,

Fig. 9. Comparative plans and sections, to scale: A. Great aula of Floris V in The Hague; B. Church of Our Lady in Damme; C. Beguinage church in Louvain; D. Dominican church in Ghent; E. St John's Hospital in Bruges; F. Cloth hall in Louvain; G. Cloth hall and belfry in Bruges; $\mathrm{H}$. Cloth hall and belfry in Ypres; (THOC, 2006).
"Cathédrales aux confins du Royaume et de l'Empire: les églisesmères de Tournai, Cambrai et Liège", in ibidem, p. 129-137. Also: Thomas Coomans \& Luc F. Genicot, "L'architecture religieuse: le XIII siècle", in Buyle, Coomans, Esther \& Genicot, L'architecture gothique en Belgique, p. 33-46.

7 Thomas Coomans, "L'architecture", in Christian Heck (ed.), L'art flamand et hollandais. Le siècle des Primitifs, $1380-1520$ (L'art et les grandes cités), Paris, 2003, p. 7-I20 and 54I-59I; Peter KURMANN, "Architektur der Spätgotik in Frankreich und den Niederlanden", in Rolf Toman (ed.), Die Kunst der Gotik. Architektur, Skulptur, Malerei, Cologne, 1998, p. 156-187.

${ }^{8}$ Raymond M. Lemaire, "L'architecture gothique", in Paul FieRENS (ed.), L'art en Belgique du Moyen Áge à nos jours, $4^{\text {th }} \mathrm{ed}$., vol. I, Brussels, 1957, p. 67-100; Herman JanSE, Rudolf MeischKe, Johannes H. van Mosselveld \& Frieda Van Tyghem, Keldermans. Een architectonisch netwerk in de Nederlanden, 's-Gravenhage, 1987 .

${ }^{9}$ Discussed in: Thomas Coomans, “'Brabantse gotiek' of 'Gotiek in Brabant'? Ontstaan van een architectuurschool, status quaestionis en onderzoeksperspectieven", in La Ville Brabançonne. Treizième colloque, Louvain I8-I9 octobre 2002, a special issue of Bijdragen tot de Geschiedenis, University of Antwerp, 86/3-4, 2003, p. 24I-27I.

${ }^{10}$ Elizabeth Den Hartog, "Op dat eynde van onsen lande. Kerkelijke architectuur in Holland en Zeeland ten tijde van de Henegouwse graven", in Dick E.H. DEN Boer, Erich H.P. Cordfunke \& Herbert SARFATIJ (ed.), I29g: één graaf, drie graafschappen. De vereniging van Holland, Zeeland en Henegouwen, Hilversum, 2000, p. 163-18I; Simon BRIGODE, L'architecture religieuse dansle sud-ouest de la Belgique, I. Des origines à la fin du XIV siècle, Brussels, I950, p. 229-235.

${ }^{11}$ Leo Helten, Kathedralen für Bürger. Die St. Nikolauskirche in Kampen und der Wandel architektonischer Leitbilder städtischer Repräsentation im 14. Jahrhundert (Clavis kunsthistorische monografieën, 13), Utrecht, 1994.

${ }^{12}$ Except the very hypothetical Westphalian influence at the SintGenoveva church of Oplinter around 1300-1310, attributed to a certain Franco of Linter. See: Raymond M. Lemaire, Les origines du style gothique en Brabant: la formation du style gothique brabançon. Les églises de l'ancien quartier de Louvain, Antwerp, 1949, p. 16 and I88-189.

${ }^{13}$ Jacques Halflants, De Sint-Sulpitiuskerk te Diest. Kunsthistorische studie, vol. I, Diest, 1992, p. I4 and 35-62.

${ }^{14}$ This was similar to the plans for the choirs of Saint-Père-sousVézelay (thirteenth century), and for the cathedrals of Séez (c. I270), Uppsala (c. 1273), and Châlons-sur-Marne (c. 1285), SaintOuen in Rouen (c. 1318), and Vendôme (1306). In Diest, only the two first chapels were built, while the three other were left unfinished at the foundation level.

15 Raymond M. Lemaire, L'architecture gothique, in Fierens, L'art en Belgique, p. 67-100 (esp. p. 85) (see note 8). A first critic was: Michel De WAHA, "À propos de l'influence de l'architecture bourguignonne en Brabant: l'église abbatiale de Villers", in Bulletin de la Commission royale des Monuments et Sites, 6, 1977, p. 37-63. 
${ }^{16}$ Lemaire, Les origines du style gothique en Brabant, p. 86-92 (see note 12$)$.

17 Thomas Coomans, "Entre France et Empire: L'architecture dans le duché de Brabant au temps de Jeanne de Brabant et Wenceslas de Luxembourg (1355-1406)", in Revue de l'Art (forthcoming).

${ }^{18}$ Edward J. Haslinghuis \& Cornelis J.A.C. Peeters, De Dom van Utrecht (De Nederlandse monumenten van geschiedenis en kunst, 2/I), 's-Gravenhage, 1965, p. 203 (for the exterior), 404-447 (for the towers).

${ }^{19}$ Haslinghuis \& Peeters, De Dom van Utrecht, p. 227-26I and 316-317 (see note I8); HeLten, Kathedralen für Bürger, p. IOIIO3 (see note II).

${ }^{20}$ Aart J.J. Mekning, Het spel met toren en kapel. Bouwen pro en contra Bourgondië van Groningen tot Maastricht (Clavis kleine kunsthistorische monografieën, I2), Zutphen, 1992.

${ }^{21}$ Timber is tree-ring dated 1386.

22 Wim Blockmans, Walter Prevenier, Edward Peeters \& Lizabeth Fackelman, The Promised Land: The Low Countries under Burgundian Rule, I369-I530 (The Middle Ages Series), Philadelphia, I999.

${ }^{23}$ Henri Pirenne, Histoire de la Belgique, $2^{\text {nd }}$ ed., Brussels, 19021908 (uses the beginning of the fourteenth century as a break between volumes I and 2); Jan A. van Houtte, Jan Frederik Niermeyer, Jacob Presser, Jan Romein \& Hans VAN Werveke (ed.), Algemene Geschiedenis der Nederlanden, Utrecht-Antwerp, 1950-1951 (uses the year 1305 - the date of the Treaty of Athis-surOrge between France and Flanders- as a break between volumes 2 and 3 ). In the last version of the general history of the Low Countries, the year 1300 is presented as a key moment for the socioeconomic history: Algemene Geschiedenis der Nederlanden. Middeleeuwen, vol. 4, Haarlem, 1980, p. II-I34.

${ }^{24}$ Today, the national feast of the Flemish Region on II July commemorates the Battle of the Golden Spurs.

${ }^{25}$ Theo Luy Kx, Het grafelijk geslacht Dampierre en zijn strijd tegen Filips de Schone (Keurreeks van het Davidsfonds, 47), Louvain, 1952.

${ }^{26}$ This has recently been confirmed by tree-ring analysis: $1288 \pm$ 6. See Dirk Jan DE VRIES, "Vergelijkend natuurwetenschappelijk dateringsonderzoek", in Bulletin van de Koninklijke Nederlandse Oudheidkundige Bond, 99/3, 2000, p. 74-84 (76-77).

${ }^{27}$ Aart J.J. Mekкıng, "Die Aula Palatii in Den Haag”, in Zeitschrift für Kunstgeschichte, 60, 1997, p. 308-333; Aart J.J. Mekking, "De 'Grote zaal' van Floris V te Den Haag. Een onderzoek naar de betekenis van het concept", in Holland in wording (Muidenbergsymposium, 5), Hilversum, 1991, p. 65-90.

${ }^{28}$ See the archaeological reports by Philippe DeSPRIET, in Archeologische en historische monografieën van Zuid-West-Vlaanderen, 2I, 1990, to 45, 200 I.

${ }^{29}$ Peter SPUfFord, Power and Profit. The Merchant in Medieval Europe, London, 2002, p. 228-255; John H. Munro, Textiles, Towns and Trade. Essays in the Economic History of Late-Medieval England and the Low Countries, Aldershot, 1994; Marc Boone \& Walter Prevenier (ed.), Drapery Production in the Late Medieval Low Countries: Markets and Strategies for Survival (I $4^{\text {th }}-16^{\text {th }}$ centuries), Proceedings of the colloquium of Ghent, 28 April 1992, Louvain-Apeldoorn, 1993; Erik Aerts \& John H. Munro, Tex- tiles of the Low Countries in European Economic History. Proceedings of the Tenth International Economic History Congress, Louvain, 1990; Dewilde, Ervynck \& Wielemans (ed.), Ypres and the Medieval Cloth Industry, 1998 (see note 2).

${ }^{30}$ Octaaf Mus, "L'évolution de la ville d'Ypres depuis l'origine jusqu'à I400”, in Dewilde, ERvynck \& Wielemans, Ypres and the Medieval Cloth Industry, p. 43-53 (see note 3).

${ }^{31}$ Michiel Heirman, Vlaamse belforten, werelderfgoed, Louvain, 2003, p. 19-39.

32 Thérèse VAN Den Noortgaete, “Tournai. Le beffroi”, in Jacques Deveseleer (ed.), Le patrimoine exceptionnel de Wallonie, Namur, 2004, p. 221-224.

${ }^{33}$ Firmin De Smidt, "Het verhoudingssysteem van 'dbeweerp vanden beelfroete' van Gent", in Mededelingen van de Koninklijke Academie voor wetenschappen, letteren en schone kunsten van België. Klasse der schone kunsten, 37/2, 1975, p. 3-30. Colour reproduction in Buyle, Coomans, Esther \& Genicot, L'architecture gothique en Belgique, p. 28 (see note 5).

${ }^{34}$ Alphonse Vandenpeereboom, Les halles d'Ypres, Ypres, 1878 ; Bouwen door de eeuwen heen, Inventaris van het cultuurbezit in België, vol. inn, West-Vlaanderen, Ieper, Turnhout, 1987, p. 117132.

${ }^{35}$ Bouwen door de eeuwen heen, Inventaris van het cultuurbezit in België, vol. 18na, Stad Brugge, oudste kern, Turnhout, 1999, p. 195202.

${ }^{36}$ Jérôme Eeckhout \& David Houbrechts, De bekappingen van de Hallen in Brugge, unpublished rapport, Centre Européen d'Archéométrie, Laboratoire de dendrochronologie, Liège, April 2006. Courtesy Nathalie Vernimme and Dirk Van Eenhooge.

${ }^{37}$ Luc Devliegher, Van Waterhalle tot Provinciaal Hof, Bruges, 1994, p. 9-39.

${ }^{38}$ René MAere, De Lakenhalle te Leuven en de Brabantsche hooggothiek (Mededelingen van de Koninklijke Vlaamsche Academie van België, Klasse der Schone Kunsten, 6/I), Antwerp-Utrecht, I944; L. HisetTe, "Halle aux draps, ou Halles universitaires de Louvain", in Revue de l'Art Chrétien, 52, 1909, p. 211-226 and 369-377.

${ }^{39}$ Bouwen door de eeuwen heen, Inventaris van het cultuurbezit in België, vol. 9n, Stad Mechelen, binnenstad, Ghent, 1984, p. 172179 .

${ }^{40}$ See general introduction with recent bibliography in: Griet MARÉCHAL, "Les hôpitaux au Moyen Âge", in Marjan Buyle, Sigrid Dehaeck \& Jacques Deveseleer (ed.), L'architecture hospitalière en Belgique (M\&L-Cahier, II), Brussels, 2005, p. 2635 .

${ }^{41}$ John D. Thompson \& Grace Goldin, The Hospital: A Social and Architectural History, New Haven-London, 1975; Dankwart Leistikow, Dix siècles d'architecture hospitalière en Europe. Une histoire de l'architecture hospitalière, Ingelheim am Rhein, 1967; Ulrich Craemer, Das Hospital als Bautyp des Mittelalters, Cologne, 1963 .

${ }^{42}$ With special thanks to Dirk Van Eenhooge and Patrick Hoffsummer, for having allowed me to use the unpublished results of recent tree-ring analysis in Bruges and Damme.

${ }^{43}$ Leo Van Puyvelde, Un hôpital du Moyen Age et une abbaye y annexée: La Biloke de Gand, étude archéologique, Ghent, 1925, p. II-52; Jeannine Baldewijns \& Marie Christine LaLEMan, "Gand, hôpitaux de la Byloke", in L'architecture hospitalière en Bel- 
gique, p. 152-155 (see note 40). For its Cistercian context, see: Thomas Coomans, "Cistercian Nunneries in the Low Countries: the Medieval Architectural Remains", in Studies in Cistercian Art and Architecture, 6, ed. Meredith P. Lillich (Cistercian Studies Series, I94), Kalamazoo, 2005, p. 6I-I3I (II9-I23).

${ }^{44}$ Patrick Hoffsummer (ed.), Les charpentes $d u X I^{e}$ au XIX ${ }^{e}$ siècle. Typologie et évolution en France du Nord et en Belgique (MonumCahiers du Patrimoine, 62), Paris, 2002, p. 192-193 and 268-270.

${ }^{45}$ Jean-Pierre Esther, "Monumentenbeschrijving en bouwgeschiedenis", in Sint-Janshospitaal Brugge, II88/1976, vol. I, Bruges, p. 259-322 ; Eva TAHON, "Bruges, Hôpital Saint-Jean", in Larchitecture hospitalière en Belgique, p. IIO-IIs (see note 40).

${ }^{46}$ Bouwen door de eeuwen heen, Inventaris van het cultuurbezit in België, vol. I8nb Zuid, Stad Brugge, middeleeuwse stadsuitbreiding zuid, Turnhout, 2004, p. 337-356.

${ }^{47}$ Eva TAhon, “Bruges, Notre-Dame de la Poterie”, in L'architecture hospitaliere en Belgique, p. 104-107 ; Bouwen door de eeuwen heen, Inventaris van het cultuurbezit in België, vol. I $8 \mathrm{nb}$ Noord, Stad Brugge, middeleeuwse stadsuitbreiding noord, Turnhout, 2004, p. 406-4I2.

48 Mieke De Jonghe, "Damme, Hôpital Saint-Jean", in L'architecture hospitalière en Belgique, p. 134-137 (see note 40); Bouwen door de eeuwen heen, Inventaris van het bouwkundig erfgoed. Provincie West-Vlaanderen, Gemeente Damme, vol. I, Brussels, 2006, p. 82-88.

${ }^{49}$ Luc Devliegher, "De opkomst van de kerkelijke gotische bouwkunst in West-Vlaanderen gedurende de XIII' eeuw", in Bulletin de la Commission royale des monuments et des sites, 5, 1954, p. 179-345, especially p. 217-228.

${ }^{50}$ Paul Rolland, L'église Saint-Brice à Tournai aux époques préromane, romane et gothique (Recueil des travaux du Centre de recherches archéologiques sous le patronage du Commissariat général à la restauration du pays et de la Direction générale des beaux-arts, 4), Antwerp, 1944, p. 37-47; René MAERE, "SaintBrice te Doornijk en de Vlaamsche Hallekerk", in Mededelingen van de Koninklijke Vlaamsche Academie voor wetenschappen, letteren en schone kunsten van België. Klasse der schone kunsten, 3, 1940, p. 3-10.

${ }^{51}$ Patrick Devos, Onderzoek van het koor van de Sint-Walburgakerk te Oudenaarde. Bijdrage tot de studie van de hallekerk in Vlaanderen, met een voorstudie over het ontstaan van Oudenaarde, Audenarde, 1976, p. 195-217.

${ }^{52}$ Philippe Despriet, De Kortrijkse Sint-Maartenskerk. Bouwgeschiedenis en archeologisch onderzoek (Archeologische en historische monografieën van Zuid-West-Vlaanderen, 27), Courtrai, 1992, p. 28-36.

53 Jacques ThiéBAut, "Les Hallenkerken de la Flandre Maritime française et leur place dans l'architecture religieuse médiévale”, in Flandria Maritima, I, 2000, p. 13-31.

${ }^{54}$ Good discussions and reconstructions of such complex processes are to be found in: Herman Janse, De Oude Kerk te Amsterdam, bouwgeschiedenis en restauratie, Zeist-Zwolle, 2004, p. 23-220; Karel Emmens, De Sint-Joriskerk te Amersfoort, van hofkapel tot kapittelkerk (Amersfortia reeks, II), Amersfoort, 1998, p. 39-124.

${ }_{55}$ Pieter A. Henderikx, De oudste bedelordekloosters in het graafschap Holland en Zeeland (Hollandse Studiën, Io), Dordrecht, 1977; Walter Simons, Stad en apostolaat. De vestiging van de bedelorden in het graafschap Vlaanderen (ca.I225-ca.I350) (Verhandelin- gen van de Koninklijke Academie voor wetenschappen, letteren en schone kunsten van België, Klasse der letteren, I2I), Brussels, I987.

${ }^{56}$ Thomas Coomans, "L'architecture médiévale des ordres mendiants (Franciscains, Dominicains, Carmes et Augustins) en Belgique et aux Pays-Bas", in Revue Belge d'Archéologie et d'Histoire de l'Art, 70, 200I, p. 3-III; Thomas Coomans, "De middeleeuwse architectuur van de bedelorden (franciscanen, dominicanen, augustijnen en karmelieten) in Nederland", in Bulletin van de Koninklijke Nederlandse Oudheidkundige Bond (KNOB), , Іо /6, 2002, p. 173-200; Panayota Volti, Les couvents des ordres mendiants et leur environnement à la fin du Moyen Age: le Nord de la France et les anciens Pays-Bas méridionaux, Paris, 2003; Wolfgang Schenkluhn, Architektur der Bettelorden. Die Baukunst der Dominikaner und Franziskaner in Europa, Darmstadt, 2000.

57 Walter Simons, Guido Jan Bral, Jan Caudron \& Johan Bockstaele, Het Pand. Acht eeuwen geschiedenis van het oud dominicanenklooster te Gent, Tielt, 1991. On the stained-glass windows: Antoine De Schrijver, Yvette Vanden Bemden \& Guido Jan BRAL, Drôleries à Gand. La découverte de fragments de vitraux médiévaux au couvent des dominicains, Courtrai, I99I.

${ }^{58}$ Thomas Coomans \& Anna Bergmans, "Léglise Notre-Dame des Dominicains à Louvain (I251-I276)", Bulletin monumental, I66, 2008 (forthcoming); Thomas Coomans, "De oudste dakconstructie in de Leuvense binnenstad: bouwhistorisch onderzoek in de predikherenkerk", in Relicta. Heritage Research in Flanders, I, 2006, p. 183-212.

${ }^{59}$ Karel Emmens, Jan Kamphuis \& André Viersen, Bouwhistorische documentatie: Minderbroederskerk Maastricht, s.l., I997; Coomans, "L'architecture médiévale des ordres mendiants", p. 19-23 and 93-96 (with bibliography) (see note 56).

${ }^{60}$ Thomas Coomans, "Assisi and Cologne on the Banks of the Meuse: The Two Mediaeval Churches of the Franciscans at Maastricht", in Uta Maria BRÄUER, Emanuel S. KLINKEnBerg \& Jeroen Westerman (ed.), Kunst \& Region. Architektur und Kunst im Mittelalter. Beiträge einer Forschungsgruppe / Art \& Region. Architecture and Art in the Middle Ages. Contributions of a Research Group (Clavis Kunsthistorische Monografieën, 20), Utrecht, 2005, p. 96-II7.

${ }^{61}$ Engelbert H. TER KuILE, Deprovincie Gelderland, het kwartier van Zutphen (De Nederlandse monumenten van geschiedenis en kunst, 3/2), 's-Gravenhage, 1958, p. 240-247 and 594-607; CooMANS, "L'architecture médiévale des ordres mendiants", p. 19-23 and 106-107 (with bibliography) (see note 56).

62 Wolfgang Schenkluhn, Ordines Studentes. Aspekte zur Kirchenarchitektur der Dominikaner und Franziskaner im 13. Jahrhundert, Berlin, 1985, p. 62-68.

${ }^{63}$ Coomans, "L'architecture médiévale des ordres mendiants", 32-34 and 75-77 (with bibliography).

${ }^{64}$ Walter Simons, Cities of Ladies: Beguine Communities in the Medieval Low Countries, I200-1565, Philadelphia, 200I; Wim F. Denslagen, "Begijnhoven in Noord-Nederlandse steden”, in Bulletin van de Koninklijke Nederlandse Oudkeidkundige Bond, 77, 1978, p. 205-224.

${ }^{65}$ Anna Bergmans \& Chris De Maegd, "De Sint-Jan-de-Doperkerk van het Groot Begijnhof in Leuven”, in Monumenten en Landschappen, 4/4, 1985, p. 6-28. 
${ }^{66}$ Thomas Coomans, "Les églises des Dominicains et du Grand Béguinage à Louvain: comparaisons typologiques”, in Panayota Volti (ed.), 'Mulieres religiosae' et leur univers. Aspects des établissements béguinaux au Moyen Âge tardif. Actes de la journée d'études du 27 octobre 2001 à l'Université Paris X-Nanterre (Histoire Médiévale et Archéologie, 15), Lille-Amiens, 2003, p. 25-41.

${ }^{67}$ Dieter NuytTen, "Middeleeuwse dakkappen in het voormalige hertogdom Brabant", in Monumenten, Landschappen en Archéologie, 24/4, 2005, p. 22-36; Thomas Coomans, "De drie kapconstructies van de begijnhofkerk”, in Benny Buntinx (ed.), Hout: bouwen met bomen in Sint-Truidense monumenten, SaintTrond, 2005, p. 24-35.

${ }^{68}$ Thomas Coomans, "Saint-Christophe à Liège: la plus ancienne église du mouvement béguinal”, in Bulletin monumental, 164, 2006, p. 359-376 (esp. p. 372-373).

${ }^{69}$ Johanna Hollestelle, De steenbakkerij in de Nederlanden tot omstreeks is6o, Arnhem, 1976; Edward J. HasLINGHUis \& Herman JANSE, Bouwkundige termen. Verklarend woordenboek van de westerse architectuur-en bouwhistorie, Leiden, $3^{\text {rd }}$ ed., 1997, p. 46-49 and 314316 (with bibliography). See also Several contributions in the proceedings of Medieval Brick Architecture, 3rd international colloquium, abbey of Ten Duinen, 24-27 Oktober 2007, ed. Thomas Coomans, Johnny De Meulemeester \& Harry VAn Royen, Novi Monasterii:
Jaarboek Abdijmuseum Ten Duinen II38, 7, 2008 (forthcoming).

${ }^{70}$ Louis F. Salzman, Building in England down to 1549. A Documentary History, Oxford, 1952, p. I40.

${ }^{71}$ Hollestelle, De steenbakkerij in de Nederlanden, p. 100-132 (see note 69).

72 Dirk Schumann, "Zur Technik und Backsteinbaus in Norddeutschland. Eine historische Einführung", in Ernst BADSTUBNer, Dirk Schumann \& Claudia Hennrich (ed.), Backsteintechnologien in Mittelalter und Neuzeit (Studien zur Backsteinarchitektur, 4), Berlin, 2003, p. 9-23.

${ }^{73}$ Hypothesis developed by: Elizabeth Den Hartog, De oudste kerken van Holland. Van kerstening tot 1300 , Utrecht, Matrijs, 2002, p. 142-209.

74 Coomans, "Cistercian Nunneries in the Low Countries", p. 106-109 and 123-127 (with bibliography) (see note 47).

${ }^{75}$ Bruce M.S. Campbell (ed.), Before the Black Death. Studies in the 'Crisis' of the Early Fourteenth Century, Manchester-New York, I99I.

${ }^{76}$ The Cockerulle in Ypres (I280); the Moerlemaye in Bruges (I280); the Mal-Saint-Martin (1307-1313) and the Peace of Fexhe (1316) in Liège; the Charter of Kortenberg (1312-1314) and the Joyeuse Entrée (1356) in Brabant; Jacques van Artevelde in Ghent (1338I345), etc. 